\title{
Modeling on population growth and its adaptation: A comparative analysis between Bangladesh and India
}

\author{
A.N.M. Rezaul Karim* \\ Department of Computer Science \& Engineering, International Islamic University Chittagong, \\ Bangladesh \\ Mohammed Nizam Uddin \\ Department of Applied Mathematics, Noakhali Science and Technology University, \\ Bangladesh \\ Masud Rana \\ Department of Applied Mathematics, Noakhali Science and Technology University, \\ Bangladesh \\ Mayeen Uddin Khandaker \\ Centre for Biomedical Physics, School of Healthcare and Medical Sciences, Sunway \\ University, Selangor, Malaysia \\ M. R. I. Faruque \\ Space Science Centre (ANGKASA), Universiti Kebangsaan Malaysia, 43600 UKM, Bangi, \\ Selangor, Malaysia \\ Sofi Mahmud Parvez \\ Department of Applied Mathematics, Noakhali Science and Technology University, \\ Bangladesh \\ ${ }^{*}$ Correspondence author. Email: zakianaser@yahoo.com
}

\section{Article Info}

https://doi.org/10.31018/

jans.v12i4.2396

Received: October 31, 2020

Revised: December 9, 2020

Accepted: December 12, 2020

\section{How to Cite}

Karim A. N. M. R. et al. (2020). Modeling on population growth and its adaptation: A comparative analysis between Bangladesh and India. Journal of Applied and Natural Science, 12(4): 688 - 701. https://doi.org/10.31018/jans.v12i4.2396

\begin{abstract}
The biggest challenge in the world is population growth and determining how society and the state adapt to it as it directly affects the fundamental human rights such as food, clothing, housing, education, medical care, etc. The population estimates of any country play an important role in making the right decision about socio-economic and population development projects. Unpredictable population growth can be a curse. The purpose of this research article is to compare the accuracy process and proximity of three mathematical model such as Malthusian or exponential growth model, Logistic growth model and Least Square model to make predictions about the population growth of Bangladesh and India at the end of 21st century. Based on the results, it has been observed that the population is expected to be 429.32 (in million) in Bangladesh and 3768.53 (in million) in India by exponential model, 211.70(in million) in Bangladesh and 1712.94 (in million) in India by logistic model and 309.28 (in million) in Bangladesh and 2686.30 (in million) in India by least square method at the end of 2100 . It was found that the projection data from 2000 to 2020 using the Logistic Growth Model was very close to the actual data. From that point of view, it can be predicted that the population will be 212 million in Bangladesh and 1713 million in India at the end of the $21^{\text {st }}$ century. Although transgender people are recognized as the third sex but their accurate statistics data is not available. The work also provides a comparative scenario of how the state has adapted to the growing population in the past and how they will adapt in the future.
\end{abstract}

Keywords: Adaptation, Basic human needs, Mathematical modeling, Population growth

\section{INTRODUCTION}

Population growth increases the demand for food, water, energy and other facilities such as education, healthcare, transportation, housing, social services, etc. (Wali et al .2012). Each state must have a clear idea of its population size and its adaptability to determine the right course of action for the future,. Population projection is a method of adapting a plan for na- tional policy formulation, economic planning and delivery of services.

Bangladesh is the 8th most populous country in the world, located in South Asia. Based on the most recent statistics, the current population of Bangladesh is 171,312,895 (Men 86,692,014, women 84,622,982 women) in 2020 and the population density of Bangladesh is $1,189.7$ per sq $\mathrm{km}$ (https://countrymeters.info/ 
en/Bangladesh/). India is the second-most populous country in the world, with almost one-fifth of the world's population. According to the latest data, India's current population is $1,399,643,335$ (Men $722,682,206$ Women $676,979,331$ ) in 2020 and the population density is 425.8 per sq $\mathrm{Km}$. (https://countrymeters.info/en/India). A variety of experiments have been performed on statistical population models. A study (Kulkarni et al., 2014) used the logical model method to project India's population growth from 2009 to 2012 and to compare the actual population of India for the same period. An error equation was also determined based on the trend line for a given period of time and the population of India was estimated for 2013 to 2022. Another research (Ofori et al., 2013) found that the exponential model offered a stronger prediction than the logistic model for population growth in Ghana. Wali et al. (2012) also researched using logistic equation as a model for population growth in Uganda. Further work on population modeling is available (Dawed et al., 2014; Shepherd and Stojkov 2007, Law et al. 2003, Wali et al., 2011) in Rwanda.

Very little research has been done on the projection of population growth in Bangladesh. Mondol et al. (2018) showed that the logistic model gives better forecast results than the Malthusian model for long-term forecasting. Another study (Ali et al., 2015) analyzed census data and forecasted Bangladesh using logistic models. However, this research has no direction on how to adapt to the population. Bangladesh and India are not just two neighbouring countries, both of which have social, cultural, economic, geographical, and above all, geopolitical relations. A competitive attitude always works between two neighbouring states to see who has been able to move forward over time. The study attempts to demonstrate as to how much of their population has been able to adapt over time. This article has also examined some recent trends to assess the challenges between the two countries and the need to overcome them, as well as to look for a possible framework for future direction. Many authors have used different models to predict the population of different countries. However, how the growing population is being accommodated and entertained by the state, how their basic needs are being met is not depicted simultaneously. We have drawn a comparative scenario of Bangladesh and India.

\section{METHODOLOGY}

The key goal of the paper is to highlight critical issues and emerging future challenges and opportunities related to population growth and adaptation. The study is based on secondary data, literature and projection analysis using a population growth model. The issue has been defined on the basis of both general and individual case studies and findings. For the analysis, the following material forms were used (a) Government reports (b) Research reports (c) Journal articles (d) projection analysis and (e) articles/reports from newspapers.

It is important to know the rate of population growth in order to project the future population of a given country. In reality, all of this data is associated with demography. In addition, scholarly papers on demographic forecasts in countries such as China (Rosario and Antony, 2017), Rwanda (Wali et al., 2011), Uganda (Wali et al., 2012), and Nigeria (Kerry et al., 2017) are also referred for methodology and approaches. Many countries use censuses to have the exact number of their populations. The method is very expensive; it requires many people and equipment. As a result, annual censuses are not carried out to predict future populations based on expenditure yearly.

Implementation: The population model is a type of mathematical model that can be used for population dynamic research. In this paper, population projections are made using the three mathematical models, namely, a) Malthusian model, b) Logistic growth model and c) Least Square model.

Malthusian growth model or exponential growth model: This model was proposed by the Englishman Thomas R. Malthus (Simon and Malthus, 2018). The growth rate is considered to be equal with a coefficient to the current population (Cohen, 1995).

Suppose the population $N_{0}$ at a certain time $t=t_{0}$ and to know the population $N$ forecast at a particular time $t=t_{1}$ in the future. Here initial condition is,

$$
\begin{aligned}
& N\left(t_{0}\right)=N_{0} \\
& \frac{d N}{d t}=r N(t), t_{0} \leq t \leq t_{1}, N\left(t_{0}\right)=N_{0}
\end{aligned}
$$

Integrating,

$$
\begin{aligned}
& \frac{d N}{d t}=r N(t) \\
& \Rightarrow \frac{d N}{N}=r d t \\
& \Rightarrow \int \frac{d N}{d t}=\int r d t \\
& \Rightarrow \ln N=r t+c \\
& \Rightarrow N=e^{r t+c} \\
& \Rightarrow N=e^{r t} \cdot e^{c} \\
& \Rightarrow N=C e^{r t} \ldots \ldots . .
\end{aligned}
$$

Given, Initial Condition is $N\left(t_{0}\right)=N_{0}$ From (i)

$\Rightarrow N\left(t_{0}\right)=C e^{r t_{0}}$

From (ii) \& (iii)

$N_{0}=C e^{r t_{0}}$ 
$C=N_{0} e^{-r t_{0}}$

Putting the value of $\mathrm{C}$ in (i)

$$
\begin{aligned}
& N(t)=N_{0} e^{-r t_{0}} e^{r t} \\
& N(t)=N_{0} e^{r\left(t-t_{0}\right)} .
\end{aligned}
$$

This is known as simple Malthusian growth model.

Logistic growth model: Logistic model was developed by Belgian mathematician Pierre Verhulst in1838 (Brauer et al. 2001). It has been shown that population growth depends on carrying capacity and the maximum rate of growth. It has been recommended that population growth be limited. This means the rate of population growth may change depending on the relationship between the initial population and carrying capacity.

The Malthusian model was revised with a view to establishing a population proportional to both the former people and the new term.

$\frac{a-b P(t)}{a}$

Where $a$ and $b$ are the required coefficients of the population.

If population values leaning towards $a / b$, so the new term would be very small and appears to be zero. It provides an estimated realistic approach to restricting population growth.

And, using this new concept, the updated equation will be a good one. That is,

$\Rightarrow \frac{d p}{d t}=\frac{a p(t)[a-b p(t)]}{a}$

The equation is established as the Verhulst model or Logistic population growth model.

By calculating equation (vi) and following the given initial condition $P\left(t_{0}\right)=P_{0}$ then the equation (vi) becomes

$$
\begin{aligned}
& \Rightarrow \frac{d p}{d t}=a p-b p^{2} \\
& \Rightarrow \frac{d p}{p(a-b p)}=d t \ldots \ldots \ldots \text { (vii) }
\end{aligned}
$$

By separating variables

$$
\Rightarrow \frac{1}{a}\left(\frac{1}{p}+\frac{b}{a-b p}\right) d p=d t .
$$

Now integrating (viii),

$$
\Rightarrow \frac{1}{a}[\ln p-\ln (a-b p)]=t+c
$$

Given initial condition: $t=t_{0} ; P\left(t_{0}\right)=P_{0}$

So,

$$
t_{0}+c=\frac{1}{a}\left[\ln p_{0}-\ln \left(a-b p_{0}\right)\right]
$$

The Equation (ix) can be written

$$
\begin{aligned}
& \Rightarrow \frac{1}{a}[\ln p-\ln (a-b p)]=t-t_{0}+\frac{1}{a}\left[\ln p_{0}-\ln \left(a-b p_{0}\right)\right] \\
& \Rightarrow P=\frac{a / b}{1+\left(\frac{a / b}{P_{0}}-1\right) e^{\left(t_{0}-t\right)}} \ldots \ldots \ldots(x i)
\end{aligned}
$$

Taking limit as $t \rightarrow \infty$, the equation (xi) becomes

$\Rightarrow P_{\infty}=\lim _{\mathrm{t} \rightarrow \infty} \mathrm{P}=\frac{a}{b}=K$

Where $K$ is known as carrying capacity.

Substituting: $\mathrm{t}=t_{0}, t=t_{1}, t=t_{2}$ in (xi), the values of $P_{0}, P_{1}, P_{2}$ respectively where $t_{0}<t_{1}<t_{2}$ are equally spaced time values.

Then equation (xi) becomes,

$\Rightarrow \frac{b}{a}\left(1-e^{\left(t_{0}-t_{1}\right) a}\right)=\frac{1}{P_{1}}-\frac{e^{\left(t_{0}-t_{1}\right) a}}{P_{0}}$
$\Rightarrow \frac{b}{a}\left(1-e^{\left(t_{0}-t_{2}\right) a}\right)=\frac{1}{P_{2}}-\frac{e^{\left(t_{0}-t_{2}\right) a}}{P_{0}}$

Removing $\frac{b}{a}$,

$\Rightarrow e^{\left(t_{0}-t_{1}\right) a}=\frac{P_{0}\left(P_{2}-P_{1}\right)}{P_{2}\left(P_{1}-P_{0}\right)}$.

Putting this value in equation (xi)

$\Rightarrow \frac{b}{a}=\frac{P_{1}^{2}-P_{0} P_{2}}{P_{1}\left(P_{0} P_{1}-2 P_{0} P_{2}+P_{1} P_{2}\right)}$.

Consequently, restricting the value of $P$ i.e. the carrying capacity is

$\Rightarrow K=\frac{P_{1}\left(P_{0} P_{1}-2 P_{0} P_{2}+P_{1} P_{2}\right)}{P_{1}{ }^{2}-P_{0} P_{2}} \ldots \ldots \ldots$ (xiv)

From equation (xii), the growth rate

$$
\Rightarrow a=\frac{1}{\left(t_{0}-t_{1}\right)} \ln \frac{P_{0}\left(P_{2}-P_{1}\right)}{P_{2}\left(P_{1}-P_{0}\right)} \ldots \ldots \ldots \ldots(x v)
$$

the equation (xi) can be written as

$$
\therefore P(t)=\frac{K P_{0}}{P_{0}+\left(K-P_{0}\right) e^{\left(t_{0}-t\right)} \cdots \cdots \cdots}(x v i)
$$

This is known as Logistic Growth Model.

Least Square Model: When time-series table is available, the least square model is used to determine future projection based on the past trends given in the time-series table. This model is a very simple method for any projection by using a straight line developed to the past information.

$$
\begin{aligned}
Y & =a+b X \ldots \ldots \ldots \ldots(\text { xvii }) \\
a & =\frac{\sum Y}{N} \\
b & =\frac{\sum X Y}{X^{2}}
\end{aligned}
$$




$$
\begin{aligned}
& \Sigma Y=N a+b \Sigma X \ldots \ldots \ldots(x v i i i) \\
& \Sigma X Y=a \Sigma X+b \Sigma X^{2} \ldots \ldots \ldots(x i x)
\end{aligned}
$$

Where:

$$
\begin{aligned}
& \Sigma X=\text { the sum of all observations of } \mathrm{X} \\
& \Sigma Y=\text { the corresponding sum of all the } Y \text { observations. } \\
& \Sigma \mathrm{X} Y=\text { the sum of all the products of } \mathrm{X} \text { and } \mathrm{Y} . \\
& N=\text { Total number of observations. }
\end{aligned}
$$

Now we have to determine the values of $a \& b$ by equating the equations (xviii) and (xix) and then substituting these values in equation (xvii). After that, it becomes a straight line and it gives the values of $Y$ for every value of $X$. This process of calculating future projection is known as the Least Square Model.

Calculation of different models and adaptation Malthusian Model: For using this method, we determined the growth rate of both India and Bangladesh with equation (iv). From Table 1, which is below, let $t_{0}=2000 \& t=2020$. The population of India is $N_{0}=1056.58 \& N=1380$ andthe population of Bangladesh is $N_{0}=127.66 \& N=164.6$ (in million).

Then we get from (iv)

For India $N=N_{0} e^{r\left(t-t_{0}\right)}$

$\Rightarrow 1380=1056.58 e^{r(2020-2000)}$

$\therefore r=0.0127164868$

For Bangladesh $N=N_{0} e^{r\left(t-t_{0}\right)}$

$\Rightarrow 164.69=127.66 e^{r(2020-2000)}$

$\therefore r=0.0 .0121283066$

Hence the general solution for India and Bangladesh is respectively

$$
\begin{aligned}
& N(t)=1056.58 e^{0.0127164868(t-2000)} \\
& N(t)=127.66 e^{0.0 .0121283066(t-2000)}
\end{aligned}
$$

Using these general solutions, we projected the population from 2000 to 2100 both for India and Bangladesh in Table 2.

Logistic Model: Again, based on Table 1, let $t_{0}=2000, t_{1}=2010 \& t_{2}=2020$

The population of India is $P_{0}=1056.58, P_{1}=1234.28 \& P_{2}=1380$ and the population of Bangladesh is

$P_{0}=127.66, P_{1}=147.58 \& P_{2}=164.69$ (in million).

Then we get from (xiv)\& (xv), the carrying capacity $K=1723.23 M$ \& growth rate $a=0.0465456$ for
India and the carrying capacity $K=214.156 M$ \& growth rate $a=0.0406756$ for Bangladesh. Now from (xvi), the general solution of Logistic Model for India and Bangladesh is respectively

$$
\begin{aligned}
& P(t)=\frac{1820730.38}{1056.58+666.65 e^{0.0465456(2000-t)}} \\
& P(t)=\frac{27339.15496}{127.66+86.496 e^{0.0406756(2000-t)}}
\end{aligned}
$$

Using these general solutions, we projected the population from 2000 to 2100 in both India and Bangladesh in Table 2.

Least Square Model: From Table 1, We have the observation number $N=21$ and also using that table we got from the equations (xviii) \& (xix)

For India

$$
\begin{aligned}
& \Rightarrow 25779.95=21 a+231 b \\
& \Rightarrow 296059.32=231 a+3311 b
\end{aligned}
$$

Solving these equations, we got from (xvii)

$$
\begin{aligned}
Y & =a+b X \\
Y & =1049.3328095238+16.207623376623 X
\end{aligned}
$$

This is the general solution of the Least Square Model for India.

For Bangladesh

$$
\begin{aligned}
& \Rightarrow 3093.04=21 a+231 b \\
& \Rightarrow 35409.39=231 a+3311 b
\end{aligned}
$$

Solving these equations, we got from (xvii)

$$
\mathrm{Y}=127.4883+1.7999350649351 \mathrm{X}
$$

Which is the general solution of the Least Square Model for Bangladesh. Putting the values of $x=1,2,3$, .... Respectively for getting the population of $\mathrm{Y}=$ 2000, 2001, 2002....etc.

\section{RESULTS}

From Table 1, it is indicated that the growth rate of population in Bangladesh was approximately $1.97 \%$, $1.50 \%, 1.13 \%, 1.13 \%, 1.01 \%$ in $2000,2005,2010$, 2015, 2020 respectively which are nearly close with the findings in this paper of a growth rate of $1.21 \%$ by exponential and $4.07 \%$ by logistic model and the growth rate of population in India was approximately $1.78 \%, 1.59 \%, 1.36 \%, 1.12 \%, 0.99 \%$ in 2000,2005 , 2010, 2015, 2020 respectively which are nearly close with the findings in this paper of a growth rate of population $1.27 \%$ by exponential $\& 4.65 \%$ by Logistic model. Based on the result, the projected population in 2100 using the three models: exponential model, logistic growth model and least square model, comes 
out to be 3768.53 million, 1712.94 million and 2686.30 million in India respectively and also comes out to be 429.32 million, 211.70 million and309.28 million in Bangladesh respectively.

From Table 2, three mathematical models have been applied to forecast the population of Bangladesh \& India from 2000 to 2100 by using the actual population from national country meter data from 2000 to 2020. To evaluate the accuracy of growth models using actual population and projected population values, the Mean Absolute Percentage Error (MAPE) equation is used.

According to the percentages of MAPE from the last row of Table 2 and comparison of population graphs, the logistic growth model gives more accurate projection results than the least square and exponential model. Its values are closer to real values obtained from national country meter data from 2000 to 2020.Based on the results of the computed MAPE of the individual model, it is found that the exponential growth model has a MAPE of $1.94 \%$ for India \& a MAPE of $1.88 \%$ for Bangladesh which are good, the least square model has a MAPE of $0.37 \%$ for India \& a MAPE of $0.32 \%$ for Bangladesh with an interpretation of very good, the logistic growth model has a
MAPE of $0.06 \%$ for India \& a MAPE of $0.29 \%$ for Bangladesh with an interpretation of highly accurate. Comparing the models, it was found that the logistic growth model is the most accurate of all the models developed. This is because the lowest MAPE obtained implies that it is the most accurate prediction. It was found that the projection data from 2000 to 2020 using the Logistic Growth Model is very close to the actual data (Fig. 1,2). From that point of view, it can be predicted that the population will be 212 million in Bangladesh and 1713 million in India in the beginning of $22^{\text {nd }}$ century (Fig. 3,4 ).

Fig 5 shows the comparative analysis of the gross domestic product (GDP) between Bangladesh and India (Table 3). Bangladesh has surpassed its larger neighbour India in terms of GDP per capita. Fig 6 and 7 show comparative data on unemployment between Bangladesh and India over the last 20 years. It is seen that the unemployment rate in India is higher than Bangladesh (Table 4). From Table 5, the projected result also shows that the unemployment rate $6.62 \%$ and $4.47 \%$; where youth unemployment rate $28.03 \%$ and $50.55 \%$ in the year 2100 in Bangladesh and India, respectively from Figs. 12 and 13 . Fig. 8 shows the comparative data on population density per square

Table 1. Actual Population and Growth Rate both of India and Bangladesh.

\begin{tabular}{|c|c|c|c|c|}
\hline \multirow{2}{*}{ Year } & \multicolumn{2}{|c|}{ Actual Population (in Millions) } & \multicolumn{2}{|c|}{ Population Growth (In percent) } \\
\hline & India & Bangladesh & India & Bangladesh \\
\hline 2000 & 1056.58 & 127.66 & $1.78 \%$ & $1.97 \%$ \\
\hline 2001 & 1075.00 & 130.09 & $1.74 \%$ & $1.90 \%$ \\
\hline 2002 & 1093.32 & 132.48 & $1.70 \%$ & $1.84 \%$ \\
\hline 2003 & 1111.52 & 134.79 & $1.67 \%$ & $1.75 \%$ \\
\hline 2004 & 1129.62 & 136.99 & $1.63 \%$ & $1.63 \%$ \\
\hline 2005 & 1147.61 & 139.04 & $1.59 \%$ & $1.50 \%$ \\
\hline 2006 & 1165.49 & 140.92 & $1.56 \%$ & $1.36 \%$ \\
\hline 2007 & 1183.21 & 142.66 & $1.52 \%$ & $1.23 \%$ \\
\hline 2008 & 1200.67 & 144.30 & $1.48 \%$ & $1.15 \%$ \\
\hline 2009 & 1217.73 & 145.92 & $1.42 \%$ & $1.12 \%$ \\
\hline 2010 & 1234.28 & 147.58 & $1.36 \%$ & $1.13 \%$ \\
\hline 2011 & 1250.29 & 149.27 & $1.30 \%$ & $1.15 \%$ \\
\hline 2012 & 1265.78 & 151.01 & $1.24 \%$ & $1.16 \%$ \\
\hline 2013 & 1280.84 & 152.76 & $1.19 \%$ & $1.16 \%$ \\
\hline 2014 & 1295.60 & 154.52 & $1.15 \%$ & $1.15 \%$ \\
\hline 2015 & 1310.15 & 156.26 & $1.12 \%$ & $1.13 \%$ \\
\hline 2016 & 1324.52 & 157.98 & $1.10 \%$ & $1.10 \%$ \\
\hline 2017 & 1338.68 & 159.69 & $1.07 \%$ & $1.08 \%$ \\
\hline 2018 & 1352.64 & 161.38 & $1.04 \%$ & $1.06 \%$ \\
\hline 2019 & 1366.42 & 163.05 & $1.02 \%$ & $1.03 \%$ \\
\hline 2020 & 1380.00 & 164.69 & $0.99 \%$ & $1.01 \%$ \\
\hline
\end{tabular}

Source: https://www.macrotrends.net/countries/IND/india/population;https://www.macrotrends.net/countries/IND/Bangladesh/population; from 2000 to 2020 . 
Karim A. N. M. R. et al. / J. Appl. \& Nat. Sci. 12(4): 688 - 701 (2020)

Table 2. Projected population both of India and Bangladesh from 2000 to 2100.

\begin{tabular}{|c|c|c|c|c|c|c|}
\hline \multirow{3}{*}{ Year } & \multicolumn{6}{|c|}{ Projected Population (in Millions) } \\
\hline & \multicolumn{2}{|c|}{ Malthusian Model } & \multicolumn{2}{|c|}{ Logistic Model } & \multicolumn{2}{|c|}{ Least Square Model } \\
\hline & India & Bangladesh & India & Bangladesh & India & Bangladesh \\
\hline 2000 & 1056.58 & 127.66 & 1056.58 & 127.66 & 1065.54 & 129.29 \\
\hline 2001 & 1070.10 & 129.22 & 1075.50 & 129.75 & 1081.75 & 131.09 \\
\hline 2002 & 1083.80 & 130.79 & 1094.21 & 131.82 & 1097.96 & 132.89 \\
\hline 2003 & 1097.67 & 132.39 & 1112.68 & 133.87 & 1114.16 & 134.69 \\
\hline 2004 & 1111.71 & 134.01 & 1130.90 & 135.90 & 1130.37 & 136.49 \\
\hline 2005 & 1125.94 & 135.64 & 1148.86 & 137.91 & 1146.58 & 138.29 \\
\hline 2006 & 1140.35 & 137.30 & 1166.54 & 139.90 & 1162.79 & 140.09 \\
\hline 2007 & 1154.94 & 138.97 & 1183.94 & 141.86 & 1178.99 & 141.89 \\
\hline 2008 & 1169.73 & 140.67 & 1201.03 & 143.79 & 1195.20 & 143.69 \\
\hline 2009 & 1184.70 & 142.38 & 1217.82 & 145.70 & 1211.41 & 145.49 \\
\hline 2010 & 1199.86 & 144.12 & 1234.28 & 147.58 & 1227.62 & 147.29 \\
\hline 2011 & 1215.21 & 145.88 & 1250.42 & 149.43 & 1243.82 & 149.09 \\
\hline 2012 & 1230.76 & 147.66 & 1266.22 & 151.25 & 1260.03 & 150.89 \\
\hline 2013 & 1246.51 & 149.46 & 1281.67 & 153.05 & 1276.24 & 152.69 \\
\hline 2014 & 1262.47 & 151.29 & 1296.79 & 154.81 & 1292.45 & 154.49 \\
\hline 2015 & 1278.62 & 153.13 & 1311.55 & 156.54 & 1308.65 & 156.29 \\
\hline 2016 & 1294.99 & 155.00 & 1325.95 & 158.23 & 1324.86 & 158.09 \\
\hline 2017 & 1311.56 & 156.89 & 1340.00 & 159.90 & 1341.07 & 159.89 \\
\hline 2018 & 1328.35 & 158.81 & 1353.70 & 161.53 & 1357.28 & 161.69 \\
\hline 2019 & 1345.34 & 160.74 & 1367.03 & 163.13 & 1373.49 & 163.49 \\
\hline 2020 & 1362.56 & 162.70 & 1380.00 & 164.69 & 1389.69 & 165.29 \\
\hline 2025 & 1452.01 & 172.88 & 1439.53 & 172.00 & 1470.73 & 174.29 \\
\hline 2030 & 1547.33 & 183.68 & 1490.48 & 178.47 & 1551.77 & 183.29 \\
\hline 2035 & 1648.91 & 195.17 & 1533.49 & 184.11 & 1632.81 & 192.29 \\
\hline 2040 & 1757.16 & 207.37 & 1569.36 & 188.99 & 1713.85 & 201.29 \\
\hline 2045 & 1872.51 & 220.33 & 1599.01 & 193.17 & 1794.88 & 210.29 \\
\hline 2050 & 1995.43 & 234.11 & 1623.31 & 196.72 & 1875.92 & 219.28 \\
\hline 2055 & 2126.43 & 248.74 & 1643.09 & 199.71 & 1956.96 & 228.28 \\
\hline 2060 & 2266.02 & 264.30 & 1659.11 & 202.22 & 2038.00 & 237.28 \\
\hline 2065 & 2414.78 & 280.82 & 1672.03 & 204.32 & 2119.04 & 246.28 \\
\hline 2070 & 2573.31 & 298.38 & 1682.41 & 206.06 & 2200.07 & 255.28 \\
\hline 2075 & 2742.24 & 317.03 & 1690.72 & 207.50 & 2281.11 & 264.28 \\
\hline 2080 & 2922.26 & 336.85 & 1697.37 & 208.70 & 2362.15 & 273.28 \\
\hline 2085 & 3114.10 & 357.91 & 1702.68 & 209.68 & 2443.19 & 282.28 \\
\hline 2090 & 3318.53 & 380.28 & 1706.90 & 210.49 & 2524.23 & 291.28 \\
\hline 2095 & 3536.38 & 404.06 & 1710.27 & 211.15 & 2605.26 & 300.28 \\
\hline 2100 & 3768.53 & 429.32 & 1712.94 & 211.70 & 2686.30 & 309.28 \\
\hline MAPE & $1.94 \%$ & $1.88 \%$ & $0.06 \%$ & $0.29 \%$ & $0.37 \%$ & $0.32 \%$ \\
\hline Interpretation & Good & Good & Highly accurate & Highly accurate & Verygood & Very good \\
\hline
\end{tabular}

kilometer between Bangladesh and India in the last 20 years. It is seen that the population density per square kilometer in Bangladesh is higher than in India. The projection also shows that the population density 2094.86 and 821.02 persons per square kilometer in the year 2100 in Bangladesh and India, respectively (Fig 14). Fig. 9 indicates that around 30\% of people are completely away from the light of education. Table 9 shows comparative data on the amount of arable land in Bangladesh and India over the last 45 years. From table 10, Data analysis projected that Agricultural land would be $1892478.88 \mathrm{sq}$ $\mathrm{km}$ in 2100 in India and1512.43 sq km in 2070 and 28354.67sq km in 2100 in Bangladesh. Fig15 shows that cultivable land is declining in Bangladesh. On the other hand, cultivable land in India (Fig 16) is not declining. Figs. 10 and 11 show comparative data of health services between Bangladesh and India in the last 17 years. It is seen that health care in Bangladesh is less than in India. 


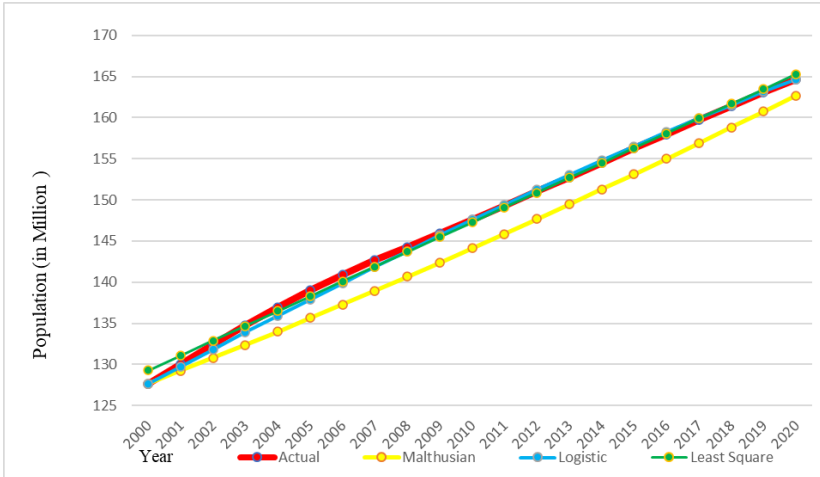

Fig. 1. Population growth in Bangladesh from 2000 to 2020. The Red line indicates the actual growth of the population during the year 2000 to 2020.

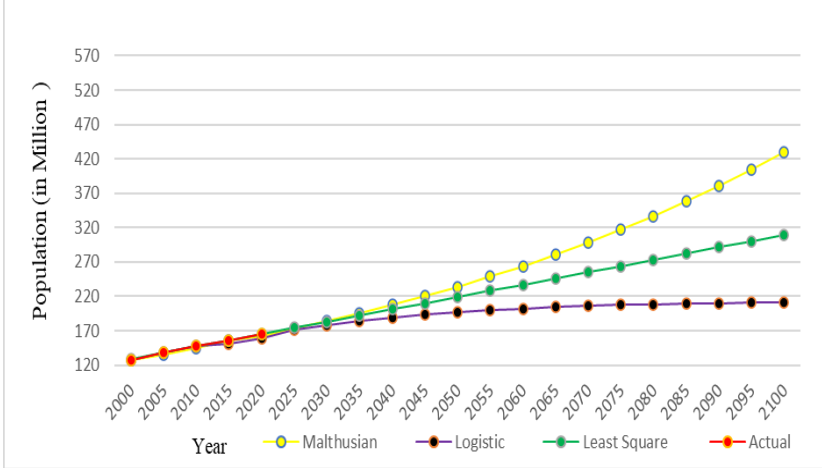

Fig. 3. Projected population of Bangladesh 2000-2100 (Estimated by Malthusian, Logistic and least Square model).

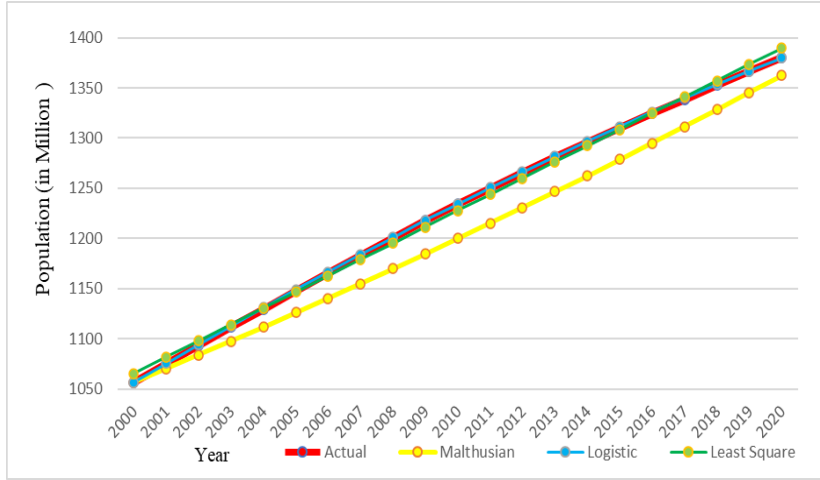

Fig. 2. Population growth in India from 2000 to 2020. The Red line indicates the actual growth of the population during the year 2000 to 2020.

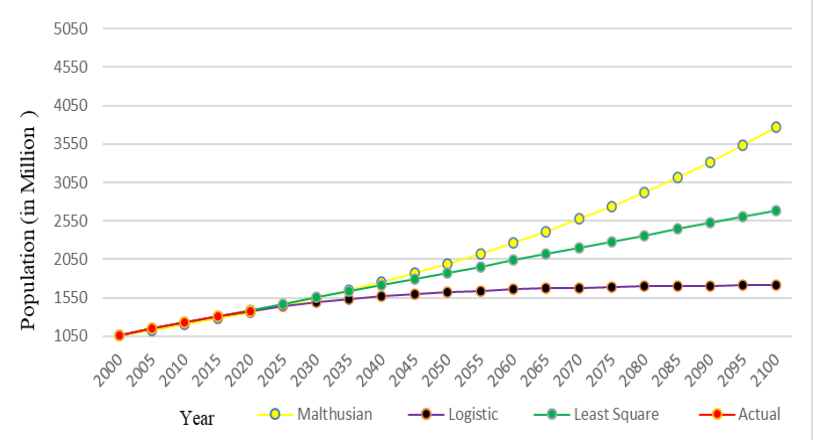

Fig. 4. Projected population of India 2000-2100 (Estimated by Malthusian, Logistic and least Square model).

Table 3. Historical Data of GDP for India and Bangladesh from 2000 to 2019.

\begin{tabular}{lllllll}
\hline \multirow{2}{*}{ Year } & \multicolumn{2}{l}{ Indian GDP - Historical Data } & & \multicolumn{3}{l}{ Bangladesh GDP - Historical Data } \\
\cline { 2 - 6 } & GDP & Per Capita & Growth & GDP & Per Capita & Growth \\
\hline 2000 & \$468.39B & $\$ 443$ & $3.84 \%$ & $\$ 53.37 \mathrm{~B}$ & $\$ 418$ & $5.29 \%$ \\
2001 & \$485.44B & $\$ 452$ & $4.82 \%$ & $\$ 53.99 \mathrm{~B}$ & $\$ 415$ & $5.08 \%$ \\
2002 & \$14.94B & $\$ 471$ & $3.80 \%$ & $\$ 54.72 \mathrm{~B}$ & $\$ 413$ & $3.83 \%$ \\
2003 & \$67.70B & $\$ 547$ & $7.86 \%$ & $\$ 60.16 \mathrm{~B}$ & $\$ 446$ & $4.74 \%$ \\
2004 & \$709.15B & $\$ 628$ & $7.92 \%$ & $\$ 65.11 \mathrm{~B}$ & $\$ 475$ & $5.24 \%$ \\
2005 & \$20.38B & $\$ 715$ & $7.92 \%$ & $\$ 69.44 \mathrm{~B}$ & $\$ 499$ & $6.54 \%$ \\
2006 & \$440.26B & $\$ 807$ & $8.06 \%$ & $\$ 71.82 \mathrm{~B}$ & $\$ 510$ & $6.67 \%$ \\
2007 & \$1216.74B & $\$ 1028$ & $7.66 \%$ & $\$ 79.61 \mathrm{~B}$ & $\$ 558$ & $7.06 \%$ \\
2008 & \$1198.90B & $\$ 999$ & $3.09 \%$ & $\$ 91.63 \mathrm{~B}$ & $\$ 635$ & $6.01 \%$ \\
2009 & \$1341.89B & $\$ 1102$ & $7.86 \%$ & $\$ 102.48 \mathrm{~B}$ & $\$ 702$ & $5.05 \%$ \\
2010 & \$1675.62B & $\$ 1358$ & $8.50 \%$ & $\$ 115.28 \mathrm{~B}$ & $\$ 781$ & $5.57 \%$ \\
2011 & \$1823.05B & $\$ 1458$ & $5.24 \%$ & $\$ 128.64 \mathrm{~B}$ & $\$ 862$ & $6.46 \%$ \\
2012 & \$1827.64B & $\$ 1444$ & $5.46 \%$ & $\$ 133.36 \mathrm{~B}$ & $\$ 883$ & $6.52 \%$ \\
2013 & \$1856.72B & $\$ 1450$ & $6.39 \%$ & $\$ 149.99 \mathrm{~B}$ & $\$ 982$ & $6.01 \%$ \\
2014 & \$2039.13B & $\$ 1574$ & $7.41 \%$ & $\$ 172.89 \mathrm{~B}$ & $\$ 1119$ & $6.06 \%$ \\
2015 & \$2103.59B & $\$ 1606$ & $8.00 \%$ & $\$ 195.08 \mathrm{~B}$ & $\$ 1248$ & $6.55 \%$ \\
2016 & \$2294.80B & $\$ 1733$ & $8.26 \%$ & $\$ 221.42 \mathrm{~B}$ & $\$ 1402$ & $7.11 \%$ \\
2017 & \$2652.75B & $\$ 1982$ & $7.04 \%$ & $\$ 249.71 \mathrm{~B}$ & $\$ 1564$ & $7.28 \%$ \\
2018 & \$2713.17B & $\$ 2006$ & $6.12 \%$ & $\$ 274.04 \mathrm{~B}$ & $\$ 1698$ & $7.86 \%$ \\
2019 & \$2875.14B & $\$ 2104$ & $5.02 \%$ & $\$ 302.57 \mathrm{~B}$ & $\$ 1856$ & $8.15 \%$ \\
\hline
\end{tabular}

Source : https://www.macrotrends.net/countries/IND/india/gdp-growth-rate,https://www.macrotrends.net/countries/BGD/bangladesh/gdp -gross-domestic-product] 
Karim A. N. M. R. et al. / J. Appl. \& Nat. Sci. 12(4): 688 - 701 (2020)

Table 4. Unemployment rate, youth unemployment rate and density of India and Bangladesh.

\begin{tabular}{|c|c|c|c|c|c|c|}
\hline \multirow{2}{*}{ YEAR } & \multicolumn{3}{|c|}{ Bangladesh } & \multicolumn{3}{|c|}{ India } \\
\hline & $\begin{array}{l}\text { Unemployment } \\
\text { Rate }\end{array}$ & $\begin{array}{l}\text { Youth Unemploy- } \\
\text { ment Rate }\end{array}$ & Density & $\begin{array}{l}\text { Unemployment } \\
\text { Rate }\end{array}$ & $\begin{array}{l}\text { Youth Unemploy- } \\
\text { ment Rate }\end{array}$ & Density \\
\hline 2000 & $3.27 \%$ & $9.75 \%$ & 864.71 & $5.66 \%$ & $17.83 \%$ & 321.42 \\
\hline 2001 & $3.55 \%$ & $9.25 \%$ & 881.18 & $5.66 \%$ & $17.89 \%$ & 327.02 \\
\hline 2002 & $3.96 \%$ & $8.24 \%$ & 897.37 & $5.72 \%$ & $18.14 \%$ & 332.59 \\
\hline 2003 & $4.32 \%$ & $6.64 \%$ & 913.04 & $5.73 \%$ & $18.20 \%$ & 333.13 \\
\hline 2004 & $4.30 \%$ & $7.76 \%$ & 927.90 & $5.67 \%$ & $18.16 \%$ & 343.64 \\
\hline 2005 & $4.25 \%$ & $8.86 \%$ & 941.78 & $5.60 \%$ & $18.10 \%$ & 349.11 \\
\hline 2006 & $3.59 \%$ & $7.33 \%$ & 954.56 & $5.45 \%$ & $18.07 \%$ & 354.55 \\
\hline 2007 & $3.89 \%$ & $7.68 \%$ & 966.34 & $5.32 \%$ & $18.11 \%$ & 359.94 \\
\hline 2008 & $4.27 \%$ & $8.15 \%$ & 977.47 & $5.28 \%$ & $18.50 \%$ & 365.25 \\
\hline 2009 & $5.00 \%$ & $9.07 \%$ & 988.45 & $5.57 \%$ & $19.67 \%$ & 370.44 \\
\hline 2010 & $3.38 \%$ & $6.40 \%$ & 999.63 & $5.64 \%$ & $20.30 \%$ & 375.47 \\
\hline 2011 & $3.71 \%$ & $7.46 \%$ & 1011.13 & $5.64 \%$ & $20.84 \%$ & 380.06 \\
\hline 2012 & $4.06 \%$ & $8.71 \%$ & 1022.87 & $5.65 \%$ & $21.39 \%$ & 385.06 \\
\hline 2013 & $4.43 \%$ & $10.13 \%$ & 1034.76 & $5.67 \%$ & $21.85 \%$ & 389.64 \\
\hline 2014 & $4.40 \%$ & $10.46 \%$ & 1046.65 & $5.61 \%$ & $22.07 \%$ & 394.13 \\
\hline 2015 & $4.38 \%$ & $10.80 \%$ & 1058.43 & $5.57 \%$ & $22.34 \%$ & 398.55 \\
\hline 2016 & $4.35 \%$ & $11.12 \%$ & 1070.09 & $5.51 \%$ & $22.58 \%$ & 402.92 \\
\hline 2017 & $4.37 \%$ & $12.30 \%$ & 1081.66 & $5.42 \%$ & $22.72 \%$ & 407.28 \\
\hline 2018 & $4.28 \%$ & $12.15 \%$ & 1093.12 & $5.33 \%$ & $22.85 \%$ & 411.48 \\
\hline 2019 & $4.19 \%$ & $11.87 \%$ & 1104.42 & $5.36 \%$ & $23.34 \%$ & 415.67 \\
\hline 2020 & $4.15 \%$ & & 1115.55 & $5.40 \%$ & & 419.80 \\
\hline
\end{tabular}

Source: https://www.macrotrends.net/countries/IND/india/population]; https://www.macrotrends.net/countries/IND/Bangladesh/population

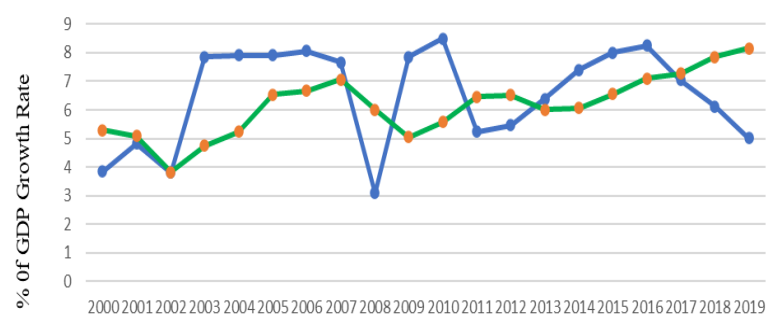

$\leadsto$-India $\leadsto$ Bangladesh

Fig. 5. GDP Growth rate for India and Bangladesh during the year 2000 to 2020 .

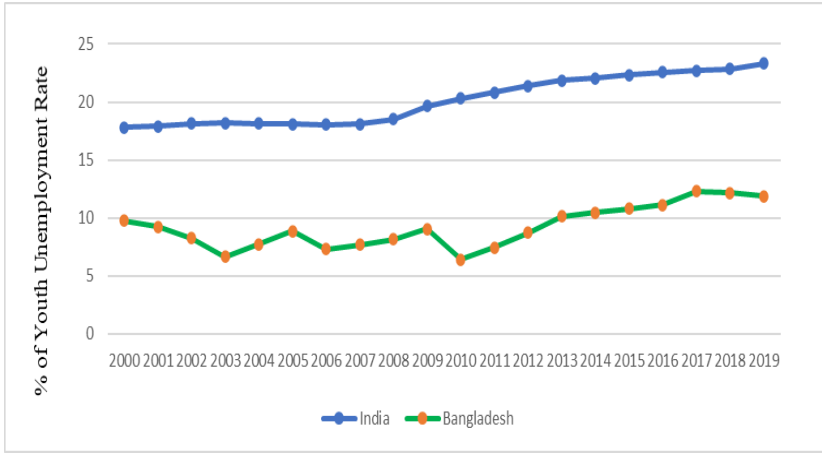

Fig. 7. Youth Unemployment Rate for India and Bangladesh during the year 2000 to 2020.

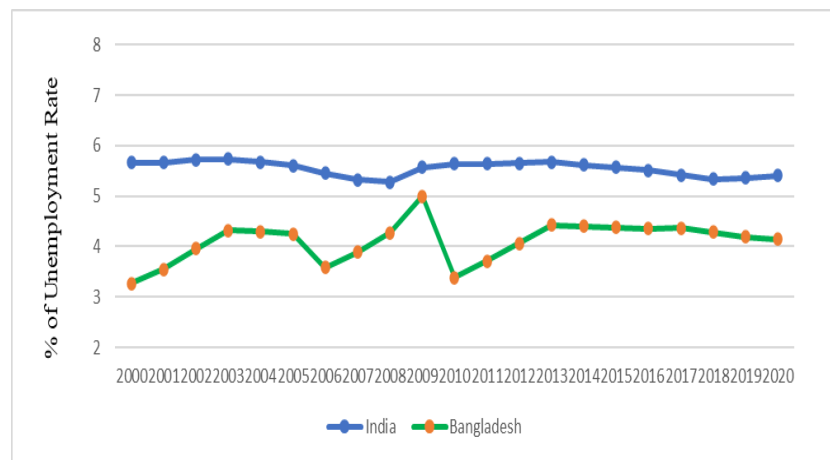

Fig. 6. Unemployment rate for India and Bangladesh during the year 2000 to 2020.

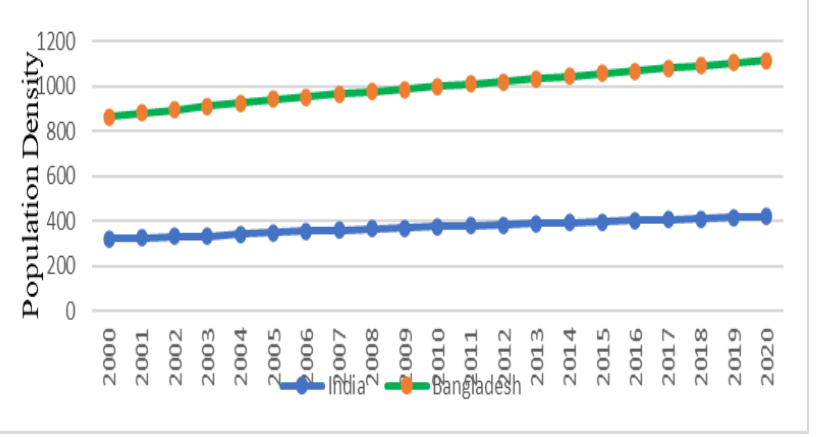

Fig. 8. Population density (person/kilometer ${ }^{2}$ ) for India and Bangladesh. 


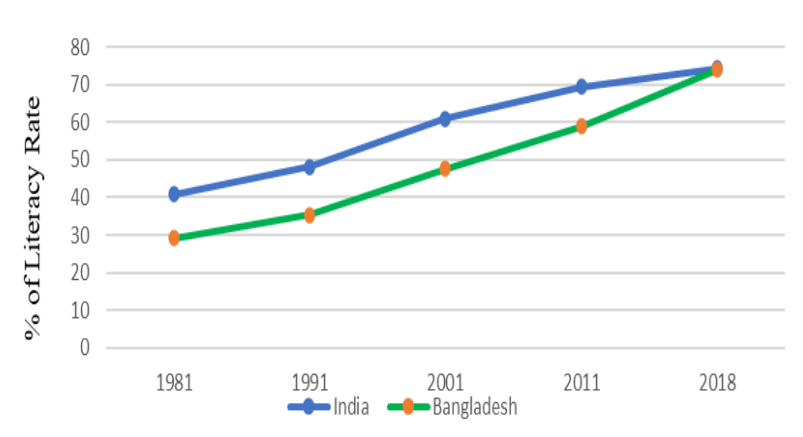

Fig. 9. Literacy rate for India and Bangladesh.

Source:[https://www.macrotrends.net/countries/BGD/bangla desh/literacy-rate;https://www.macrotrends.net/countries/IND/ind ia/literacy-rate]

Table 5. Projected unemployment rate, youth unemployment Rate and density of India and Bangladesh by using Least square model.

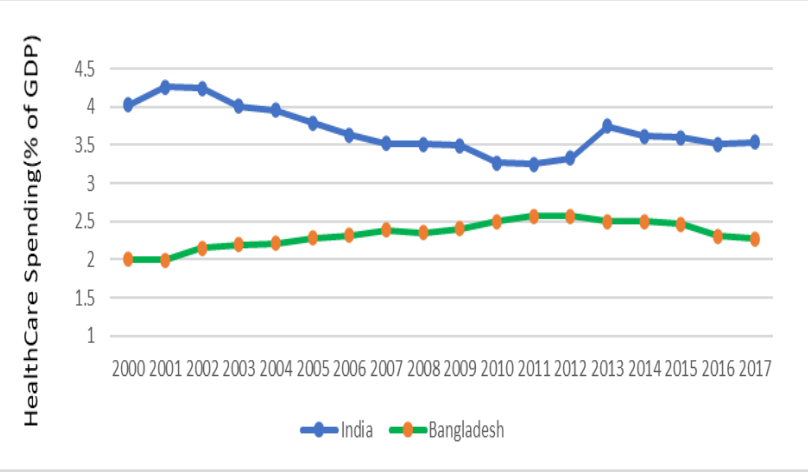

Fig. 10. Health care spending (\% of GDP) for India and Bangladesh.

\begin{tabular}{|c|c|c|c|c|c|c|}
\hline \multirow{2}{*}{ YEAR } & \multicolumn{3}{|c|}{ Bangladesh } & \multicolumn{3}{|c|}{ India } \\
\hline & $\begin{array}{l}\text { Unemployment } \\
\text { Rate }\end{array}$ & $\begin{array}{l}\text { Youth Unemploy- } \\
\text { ment Rate }\end{array}$ & Density & $\begin{array}{l}\text { Unemployment } \\
\text { Rate }\end{array}$ & $\begin{array}{l}\text { Youth Unemploy- } \\
\text { ment Rate }\end{array}$ & Density \\
\hline 2000 & $3.82 \%$ & $7.23 \%$ & 875.76 & $5.67 \%$ & $16.96 \%$ & 323.44 \\
\hline 2001 & $3.85 \%$ & $7.44 \%$ & 887.95 & $5.65 \%$ & $17.29 \%$ & 328.41 \\
\hline 2002 & $3.88 \%$ & $7.65 \%$ & 900.14 & $5.64 \%$ & $17.63 \%$ & 333.39 \\
\hline 2003 & $3.90 \%$ & $7.85 \%$ & 912.33 & $5.63 \%$ & $17.96 \%$ & 338.36 \\
\hline 2004 & $3.93 \%$ & $8.06 \%$ & 924.53 & $5.62 \%$ & $18.30 \%$ & 343.34 \\
\hline 2005 & $3.96 \%$ & $8.27 \%$ & 936.72 & $5.61 \%$ & $18.64 \%$ & 348.31 \\
\hline 2006 & $3.99 \%$ & $8.48 \%$ & 948.91 & $5.59 \%$ & $18.97 \%$ & 353.29 \\
\hline 2007 & $4.02 \%$ & $8.69 \%$ & 961.10 & $5.58 \%$ & $19.31 \%$ & 358.27 \\
\hline 2008 & $4.04 \%$ & $8.89 \%$ & 973.29 & $5.57 \%$ & $19.64 \%$ & 363.24 \\
\hline 2009 & $4.07 \%$ & $9.10 \%$ & 985.48 & $5.56 \%$ & $19.98 \%$ & 368.22 \\
\hline 2010 & $4.10 \%$ & $9.31 \%$ & 997.67 & $5.55 \%$ & $20.32 \%$ & 373.19 \\
\hline 2011 & $4.13 \%$ & $9.52 \%$ & 1009.86 & $5.53 \%$ & $20.65 \%$ & 378.17 \\
\hline 2012 & $4.16 \%$ & $9.73 \%$ & 1022.05 & $5.52 \%$ & $20.99 \%$ & 383.15 \\
\hline 2013 & $4.18 \%$ & $9.93 \%$ & 1034.24 & $5.51 \%$ & $21.32 \%$ & 388.12 \\
\hline 2014 & $4.21 \%$ & $10.14 \%$ & 1046.44 & $5.50 \%$ & $21.66 \%$ & 393.10 \\
\hline 2015 & $4.24 \%$ & $10.35 \%$ & 1058.63 & $5.49 \%$ & $22.00 \%$ & 398.07 \\
\hline 2016 & $4.27 \%$ & $10.56 \%$ & 1070.82 & $5.47 \%$ & $22.33 \%$ & 403.05 \\
\hline 2017 & $4.30 \%$ & $10.77 \%$ & 1083.01 & $5.46 \%$ & $22.67 \%$ & 408.02 \\
\hline 2018 & $4.32 \%$ & $10.97 \%$ & 1095.20 & $5.45 \%$ & $23.00 \%$ & 413.00 \\
\hline 2019 & $4.35 \%$ & $11.18 \%$ & 1107.39 & $5.44 \%$ & $23.34 \%$ & 417.98 \\
\hline 2020 & $4.38 \%$ & $11.39 \%$ & 1119.58 & $5.43 \%$ & $23.68 \%$ & 422.95 \\
\hline 2025 & $4.52 \%$ & $12.43 \%$ & 1180.54 & $5.37 \%$ & $25.36 \%$ & 447.83 \\
\hline 2030 & $4.66 \%$ & $13.47 \%$ & 1241.49 & $5.31 \%$ & $27.04 \%$ & 472.71 \\
\hline 2035 & $4.80 \%$ & $14.51 \%$ & 1302.45 & $5.25 \%$ & $28.72 \%$ & 497.59 \\
\hline 2040 & $4.94 \%$ & $15.55 \%$ & 1363.40 & $5.19 \%$ & $30.40 \%$ & 522.47 \\
\hline 2045 & $5.08 \%$ & $16.59 \%$ & 1424.36 & $5.13 \%$ & $32.08 \%$ & 547.35 \\
\hline 2050 & $5.22 \%$ & $17.63 \%$ & 1485.31 & $5.07 \%$ & $33.76 \%$ & 572.23 \\
\hline 2055 & $5.36 \%$ & $18.67 \%$ & 1546.27 & $5.01 \%$ & $35.44 \%$ & 597.10 \\
\hline 2060 & $5.50 \%$ & $19.71 \%$ & 1607.22 & $4.95 \%$ & $37.12 \%$ & 621.98 \\
\hline 2065 & $5.64 \%$ & $20.75 \%$ & 1668.18 & $4.89 \%$ & $38.80 \%$ & 646.86 \\
\hline 2070 & $5.78 \%$ & $21.79 \%$ & 1729.13 & $4.83 \%$ & $40.48 \%$ & 671.74 \\
\hline 2075 & $5.92 \%$ & $22.83 \%$ & 1790.09 & $4.77 \%$ & $42.16 \%$ & 696.62 \\
\hline 2080 & $6.06 \%$ & $23.87 \%$ & 1851.04 & $4.71 \%$ & $43.84 \%$ & 721.50 \\
\hline 2085 & $6.20 \%$ & $24.91 \%$ & 1912.00 & $4.65 \%$ & $45.52 \%$ & 746.38 \\
\hline 2090 & $6.34 \%$ & $25.95 \%$ & 1972.95 & $4.59 \%$ & $47.20 \%$ & 771.26 \\
\hline 2095 & $6.48 \%$ & $26.99 \%$ & 2033.91 & $4.53 \%$ & $48.88 \%$ & 796.14 \\
\hline 2100 & $6.62 \%$ & $28.03 \%$ & 2094.86 & $4.47 \%$ & $50.55 \%$ & 821.02 \\
\hline
\end{tabular}




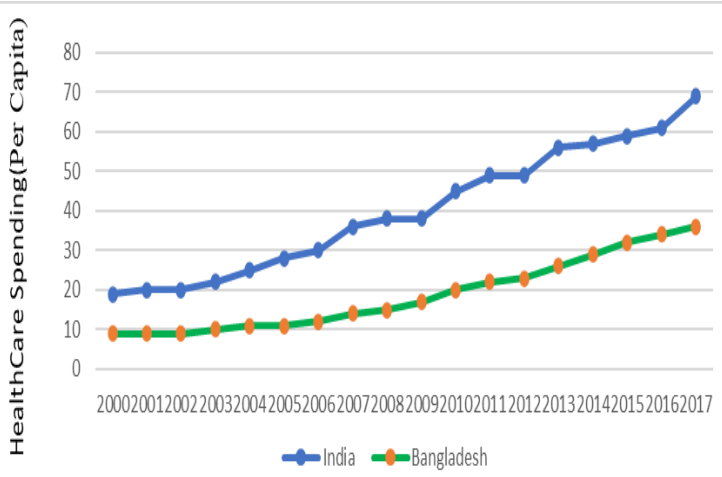

Fig. 11. Health care spending per capita for India and Bangladesh.

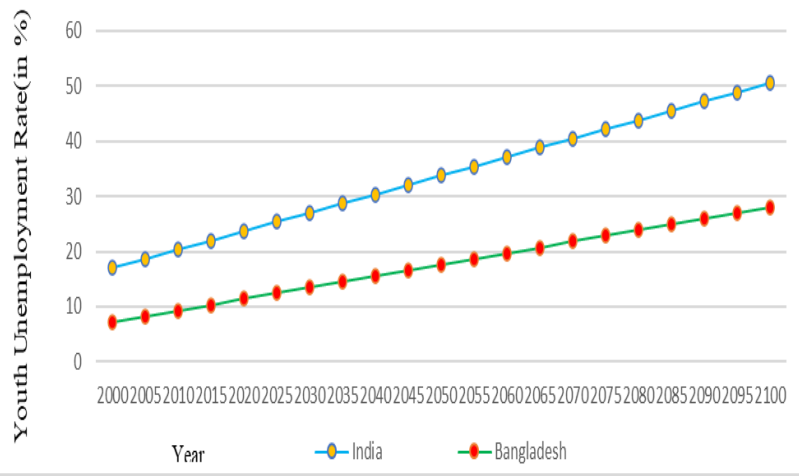

Fig. 13. Projected youth unemployment rate of India and Bangladesh during the year 2000-2100.

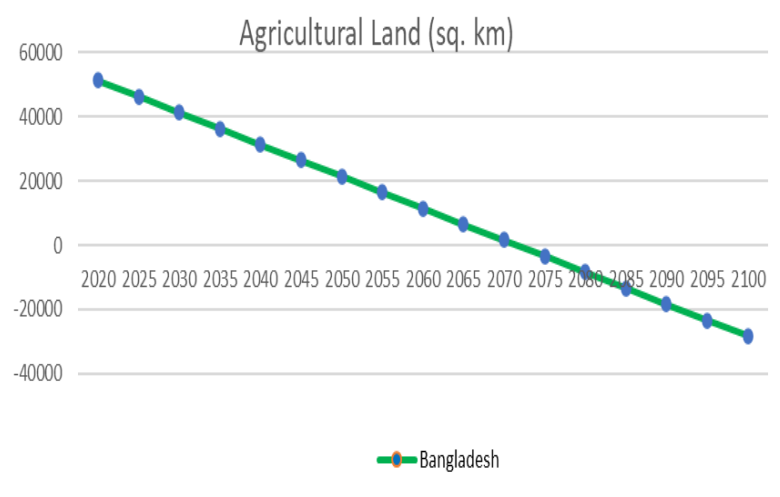

Fig. 15. Projection of agricultural land (sq. km) in Bangladesh using Least square model.

Table 6. Comparative scenario of Bangladesh and India.

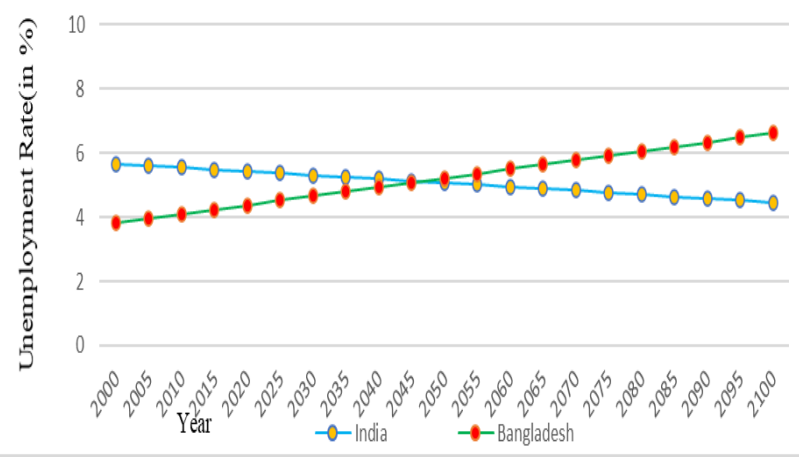

Fig. 12. Projected unemployment rate of India and Bangladesh during the year 2000-2100.

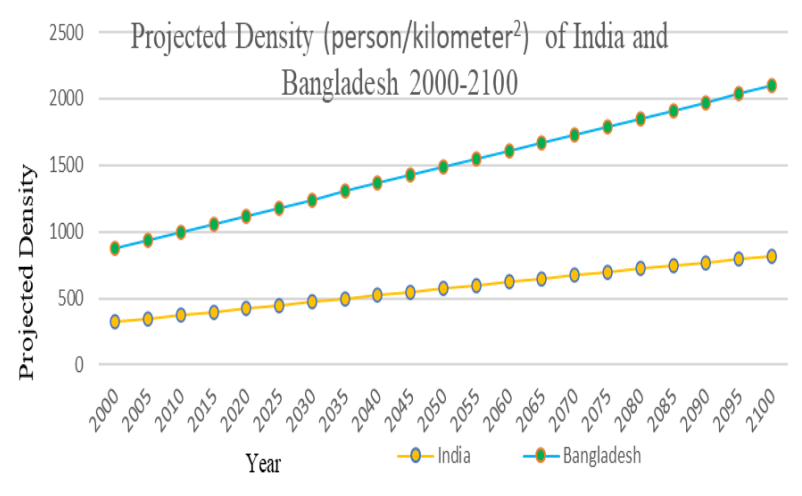

Fig. 14. Projected density (person/kilometer ${ }^{2}$ ) of India and Bangladesh during the 2000-2100.

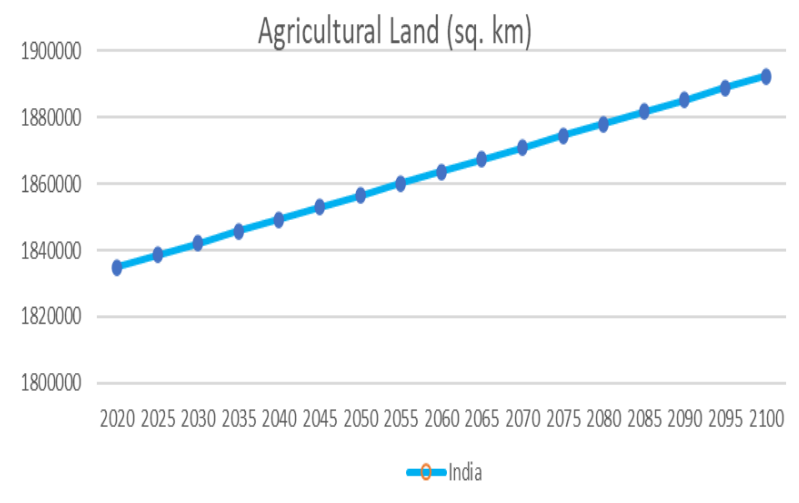

Fig. 16. Projection of agricultural land (sq. $\mathrm{km}$ ) in India using Least square model.

\begin{tabular}{llllllll}
\hline & $\begin{array}{l}\text { Population } \\
\text { growth } \\
\mathbf{( 2 0 2 0 )}\end{array}$ & $\begin{array}{l}\text { GDP } \\
\text { growth } \\
\text { rate } \\
\mathbf{( 2 0 1 9 )}\end{array}$ & $\begin{array}{l}\text { Unem- } \\
\text { ployment } \\
\text { Rate } \\
\mathbf{( 2 0 1 9 )}\end{array}$ & $\begin{array}{l}\text { Youth } \\
\text { Unem- } \\
\text { ployment } \\
\text { Rate } \\
\mathbf{( 2 0 1 9 )}\end{array}$ & $\begin{array}{l}\text { Population } \\
\text { Density } \\
\text { (person/ } \\
\mathbf{s q ~ k m )} \\
\mathbf{( 2 0 2 0 )}\end{array}$ & $\begin{array}{l}\text { Literacy } \\
\text { Rate } \\
(\mathbf{2 0 1 8})\end{array}$ & $\begin{array}{l}\text { Health } \\
\text { Care } \\
\text { Spending } \\
\mathbf{( \% )} \text { of GDP } \\
\mathbf{( 2 0 1 7 )}\end{array}$ \\
\hline Bangladesh & $1.01 \%$ & $8.15 \%$ & $4.19 \%$ & $11.87 \%$ & 1115.55 & $73.91 \%$ & $2.27 \%$ \\
India & $0.99 \%$ & $5.02 \%$ & $5.36 \%$ & $23.34 \%$ & 419.80 & $74.37 \%$ & $3.54 \%$ \\
\hline
\end{tabular}

Source: https://www.macrotrends.net/countries/ 
Karim A. N. M. R. et al. / J. Appl. \& Nat. Sci. 12(4): 688 - 701 (2020)

Table 7 . Temporal changes (2001-2011) in homeless in households in India.

\begin{tabular}{lllllll}
\hline & \multicolumn{2}{c}{ All Households } & \multicolumn{3}{c}{ House less Households } \\
\cline { 2 - 7 } & $\mathbf{2 0 0 1}$ & $\mathbf{2 0 1 1}$ & Absolute & & Percentage \\
\cline { 2 - 7 } & & & $\mathbf{2 0 0 1}$ & $\mathbf{2 0 1 1}$ & $\mathbf{2 0 0 1}$ & $\mathbf{2 0 1 1}$ \\
\hline Rural & $13,77,73,323$ & $16,85,65,486$ & $2,59,742$ & $1,92,865$ & 0.19 & 0.11 \\
Urban & $5,58,06,631$ & $8,08,88,766$ & $1,87,810$ & $2,56,896$ & 0.34 & 0.32 \\
Total & $19,35,79,954$ & $24,94,54,252$ & $4,47,552$ & $4,49,761$ & 0.23 & 0.18 \\
\hline
\end{tabular}

Source: PCA (2011)

Table 8. Temporal changes (2001-2011) in the homeless population in India.

\begin{tabular}{|c|c|c|c|c|c|c|c|c|}
\hline & & \multicolumn{7}{|c|}{ Homeless Population } \\
\hline & \multicolumn{3}{|c|}{ All Population } & \multicolumn{2}{|c|}{ Absolute } & \multicolumn{2}{|c|}{ Percentage } & \multirow[b]{2}{*}{$\begin{array}{l}\text { Growth Rate } \\
\text { (2001-2011) }\end{array}$} \\
\hline & 2001 & 2011 & $\begin{array}{l}\text { Growth Rate } \\
(2001-2011)\end{array}$ & 2001 & 2011 & $\begin{array}{l}200 \\
1\end{array}$ & 2011 & \\
\hline Rural & $74,23,02,537$ & $83,34,63,448$ & 12.3 & $11,64,877$ & $8,34,541$ & 0.16 & 0.10 & -28.4 \\
\hline Urban & $28,63,07,791$ & $37,71,06,125$ & 31.7 & $7,78,599$ & $9,38,348$ & 0.27 & 0.25 & 20.5 \\
\hline Total & $1,02,86,10,328$ & $\begin{array}{l}1,21,05,69,57 \\
3\end{array}$ & 17.7 & $19,43,476$ & $17,72,889$ & 0.19 & 0.15 & -8.8 \\
\hline
\end{tabular}

Table 9. Agricultural Land (sq. km) of Bangladesh and India.

\begin{tabular}{lll}
\hline \multirow{2}{*}{ Year } & & Agricultural Land (sq. km) \\
\cline { 2 - 3 } & Bangladesh & India \\
\hline 1970 & 96970 & 1780520 \\
1975 & 100040 & 1796940 \\
1980 & 99870 & 1802720 \\
1985 & 100270 & 1813400 \\
1990 & 103860 & 1814130 \\
1995 & 93740 & 1809450 \\
2000 & 94000 & 1809750 \\
2005 & 93110 & 1801260 \\
2010 & 92410 & 1795730 \\
2015 & 91622.402 & 1797210 \\
\hline
\end{tabular}

Source: World Bank Report [https://data.worldbank.org/indicator/AG.LND.AGRI.K2?locations=IN]

Table 10. Projection of Agricultural Land (sq. km) of Bangladesh and India.

\begin{tabular}{lll}
\hline \multirow{2}{*}{ Year } & & \multicolumn{1}{c}{ Agricultural Land (sq. km) } \\
\cline { 2 - 3 } & Bangladesh & \multicolumn{1}{l}{ India } \\
\hline 2020 & 51290.93 & 1834874 \\
2025 & 46313.08 & 1838474.38 \\
2030 & 41335.23 & 1842074.62 \\
2035 & 36357.38 & 1845675 \\
2040 & 31379.53 & 1849275.25 \\
2045 & 26401.68 & 1852875.5 \\
2050 & 21423.83 & 1856475.88 \\
2055 & 16445.98 & 1860076.12 \\
2060 & 11468.13 & 1863676.5 \\
2065 & 6490.28 & 1867276.75 \\
2070 & 1512.43 & 1870877 \\
2075 & -3465.42 & 1874477.38 \\
2080 & -8443.27 & 1878077.62 \\
2085 & -13421.12 & 1881678 \\
2090 & -18398.97 & 1885278.25 \\
2095 & -23376.82 & 1888878.5 \\
2100 & -28354.67 & 1892478.88 \\
\hline
\end{tabular}

Source: World Bank Report [https://data.worldbank.org/indicator/AG.LND.AGRI.K2?locations=BD] 


\section{DISCUSSION}

We analyzed and investigated to predict the populations for the next 80 years, which gives the carrying capacity of India \& Bangladesh is respectively around 1723.23 million\& 214.156 million, which leads to an estimated population of India \& Bangladesh around 1712.94 million\& 211.70 million in 2100 .

It is also revealed that the Mean Absolute Percentage Error (MAPE) is very low in the Logistic growth model. From this perspective, we can finally conclude that the logistic growth model yields better forecast results than the Least Square and the Malthusian model for a long-term forecast. In the economic sector, these models can be applied to estimate the simple or compound interest of investments and other sectors with dynamic populations such as education, industrial, policy, culture, environmental and demographic development etc.

The exponential growth model takes the time (t) only as an explanatory variable, the growth rate is constant, but the model can't explain the decrease of the population growth rate; this will cause a significant problem since it only measures the time trend of a population without taking into account the other factors which affect the population growth. The exponential model predicts that the population would increase without control, but this may not be the case forever. The majority of the population is limited by resources even in a short time and none is permanently isolated. Therefore, the conclusion cannot be applied to long-term population growth. The exponential model is only applicable when the population is accessible with limitless resources. In reality, there are limited resources available to the population, such as food, water, energy and space, etc. Therefore, the logistic growth model would have the best-predicted outcomes for longterm forecasts with limited resources rather than the exponential growth model. The Logistic Growth Function is based on the carrying capacity value $(\mathrm{K})$. Over time, $\mathrm{K}$ isn't a set number. Based on many situations, it is always evolving.

This projection (Fig. 12) projection indicates that the number (\%) of unemployed in Bangladesh will be higher than in India in 2100. Again, this projection (Fig 13) indicates that the number (\%) of young unemployed in India will be higher in 2100 than in Bangladesh in 2100.

Analysis of Fig 14 shows that the population per square kilometer will be very densely populated. But a report suggested that the average space of a room is $430 \mathrm{sq} / \mathrm{ft}-475 \mathrm{sq} / \mathrm{ft}$ in cities and $392 \mathrm{sq} / \mathrm{ft}$ in villages. The average size of the living room is $101 \mathrm{sq} / \mathrm{ft}-114$ $\mathrm{sq} / \mathrm{ft}$ in the cities while $91 \mathrm{sq} / \mathrm{ft}$ in villages in Bangladesh (BBS. 2018).

Bangladesh is the sixth most impoverished country in the world. There are two crores 29 lakh impoverished people in this country. India has the highest number of
26 crore 47 lakh extremely poor people in the world. This information has come up in the report of the World Bank titled 'Probability and Share Prosperity 2020: Revival of Fortune or Partner of Poverty and Prosperity: Disaster of Fate' The World Bank calls a person out of poverty or extremely poor if he earns 1.90 US dollars daily [World Bank Report, 2020,] GDP per capita is a global measure of a country's prosperity, and economists use per capita income growth in addition to GDP to analyze a country's prosperity. There is no doubt that economic growth is needed to alleviate poverty; even two decades ago, Bangladesh was called a bottomless basket because of its low per capita income and low growth in the gross domestic product (GDP) among South Asian countries. Even if this stigma is overcome, this country still has a long way to go. Prominent Indian journalist Mark Tully noted that Bangladesh's economy has been growing steadily for more than 20 years. Some development agencies have now called this country a model of development. However, about 20 percent of Bangladesh's population is still very poor. The economy is still dependent on remittances sent by workers abroad and the garment industry [Hindustan times of India]. According to a recent report by the International Monetary Fund, Bangladesh has surpassed neighboring India in terms of GDP per capita in 2020 [World Economic Outlook (WEO) report, October, 13, 2020]. Table 6 highlights that in some respects, Bangladesh is ahead of India such as, GDP is higher, the unemployment rate is lower than India.

Our study shows that cultivable land is declining as a result of population growth. A similar report states that the reduction in agricultural land was around $0.27 \%$ annually from $1976-77$ to $2010-11$ and $0.42 \%$ annually from 1976-77 to 2000-01. It increased marginally from 2000-01 to 2010-11, with an annual average of $0.14 \%$ (BBS, 2011) Another study reported a 4\% rise in total land area from 1948 to 2006 due to the reclamation of char lands and an overall decrease of $0.10 \%$ annually in cultivable land, assuming conversion to housing, road and industrial infrastructure (Rahman, 2010). Agricultural land is slowly being converted into human habitation, which can adversely affect food security as well as which could lead to severe food shortages in the coming years. Agriculture has dominant importance, as it is a major supplier of food to citizens in Bangladesh and India. The first step in understanding the current and future problems of food security is a deeper assessment of the changed agricultural system and environment.

Education is one of the basic human rights. Our research says $30 \%$ of people do not even know how to write; they don't know how to read, they don't know the alphabet. There are many discussions and questions about literacy rates. Can a person with this feature be called literate if he can only read or write his own name? According to researchers, being able to 
write this or just having knowledge of the alphabet is not a sign of literacy. Three "R's" are to be achieved in literate. There are "reading", "writing" \& "arithmetic". With these three "R's" a fourth "R" must be achieved. That is, he could write, he could read, he could do the math, and he could relate to real life. What will be the exact literacy rate if only a person who knows how to sign is excluded from the list of signatures?

Homelessness is a complicated and widespread problem. Homeless people who sleep on sidewalks, train stations, bus terminals, parks and open spaces, religious centers, cemeteries and other government places without roofs (Islam, 1997). The number of people who are homeless is increasing. 950,000 people were homeless in 1991 and the figure grew to $11,30,000$ in 2001 and 4.6 million in 2010, respectively. The figure will be raised to 8.5 million by 2021 in line with the five -year plan documents by 2021 in Bangladesh [BBS report]. From the Table 8 , the number of homeless population is 19,43,476 in 2001 and 17,72,889 in 2011 and from the Table 7,the number of house less households is 4,47,552 in 2001 and 4,49,761 in 2011 in India. There is an intimate connection between poverty and homelessness; on the other side, due to river erosion, many people become homeless. 160,000 hectares of land was lost to the rivers between 1973 and 2017. A large amount of the land was homesteads. The poor cannot purchase new land for houses and become homeless when the land is lost. Based on a study carried out by the Sweden's Raoul Wallenberg Institute of Human Rights and Independent University, 6.8 million people lost their homes because of the erosion of the rivers. Another research shows that 1.342 million people lost their homes alone during the cyclone Aila in 2010.

Although the third gender population is recognized as a citizen, there are still no accurate statistics on them. The census reveals the number and ratio of women and men, but we never get any statistics on those outside women and men. They are always excluded from the census. Where their numbers are unknown, it is not possible to take development plans. Hopefully, people of the third sex must be included in all future population forecasting studies and censuses. Future research studies need to address the factors that impact population growth to get reasonable results.

\section{Conclusion}

Our study found that there is no check and balance between population growth and its adaptation. The increase in population may lead to the expansion of some features that will reduce the carrying capacity of the land and the capability of the common property resources to meet the needs of the present and future populations. If the state cannot ensure housing, education, medical care, food, employment of the people as the population grows, crime will increase in society and people's lives will become utterly insecure and the whole human race will face a catastrophe. Agricultural land is becoming the home for the growing population. Since food security is a major concern in any country, necessary steps should be taken to protect agricultural lands from shifting to non-agricultural land use. In order to establish a holistic strategy to ensure secure food supplies and sustain peace and stability, both countries need to gather its own insights into the agricultural system. Therefore, the Government should take measures to reduce the effect of this growth, including the formulation of policies to protect the environment and natural resources in the national population policy. On the other hand, it can help in adapting plans for public social services, especially housing, education, medical care, food and human employment. Initiatives to pursue human development and bring deprivation to an end have to be coordinated, consistent and continuous across successive regimes. If there is no check and balance between population growth and its adaptation, these people will be cursed without being blessed. Our study concludes that in some respects, Bangladesh lags behind India.

\section{Conflict of interests}

There is no conflict of interest regarding the publication of this article.

\section{REFERENCES}

1.Ali, L. E., Khan, B. R., and Sams, I. S. (2015). Brief study on census and predicted population of Bangladesh using Logistic population model. Annals of Pure and Applied Mathematics, 10(1) : 41-47

2.BBS) (2011. Population census- 2011. Preliminary report. Bangladesh Bureau of Statistics (BBS), Ministry of Planning, Dhaka

3.BBS (2018). Bangladesh Sample Vital Statistics. National Volume-3 : Urban Area Report. Bangladesh Bureau of Statistics (BBS), Bangladesh

4.Brauer, F. Castillo-Chavez, C. (2001). Mathematical models in population biology and epidemiology. Texts in Applied Mathematics, volume no 40., DOI: 10.1007/978-1-4757-3516-1

5.Census (2011). Primary census abstracts, Registrar General of India, Ministry of Home Affairs, Government of India, Available at: http://www.censusindia.gov. in/2011ce nsus/ PCA/pca_highlights/pe_data.

6.Cohen, J. (1995). Human carrying capacity. Science. http:// ehsapes.pbworks.com/f/Population\%2BGrowth\%2B\%26\% 2BEarth's\%2BHuman\%2BCarrying\%2BCapacity.pdf

7.Dawed, M. Y., Koya, P. R., and Goshu, A. T. (2014). Mathematical modelling of population growth: The case of Logistic and Von bertalanffy models. Open Journal of Modelling and Simulation, 02 (04) : 113-126 https://doi.org/10.4236/ ojmsi.2014.24013

8.Islam, N. (1997). Addressing the urban poverty agenda in Bangladesh. Critical issues and the 1995 Survey findings, Dhaka: University Press Ltd.

9.Kerry, C. C., Tessy, S., Ezeora, J. N., and Iweanandu, O. J. (2017). A comparative study of mathematical and statistical models for population projection of Nigeria. 8(2) : 777785. 
10.Kulkarni, S., R Kulkarni, S., and J Patil, S. (2014). Analysis of Population Growth of India and Estimation for Future. International Journal of Innovative Research in Science, Engineering and Technology, 03(09) : 15843-15850. https:// doi.org/10.15680/ijirset.2014.0309008

11.Law, R., Murrell, D. J., \&Dieckmann, U. (2003). Population growth in space and time: spatial logistic equations. Ecology, 84 (1) : 252-262.

12.Mondol, H., Mallick, U. K., \& Biswas, M. H. A. (2018). Mathematical modeling and predicting the current trends of human population growth in Bangladesh. Advances in Modelling and Analysis A, 55(2) : 62-69. https://doi.org/10.18280/ ama_a.550204

13.Ofori, T., Ephraim, L., Nyarko, F., Keshtavar, A., Moeinaddin, M., Dehnavi, H. D., \& Oladejo, N. K. (2013). Mathematical Model of Ghana's Population Growth. International Journal of Modern Management Sciences, 2(2), 57-66.

14.PCA (2011). Primary census abstract for total population and houseless population, office of the Registrar general and census commissioner, India

15.Rosario, G. M., and Antony, M. J. (2017). Mathematical Model for Future Popu-lation Scenario In India And China-An Econometric Approach. International Journal of Scientific \& Engineering Research, 8(5) : 62.

16.Rahman, S. (2010). Six decades of agricultural land use change in Bangladesh : effects on crop diversity, productivity, food availability and the environment,1948-2006. Singapore Journal of Tropical Geography, 31: 245-269

17.Report on Bangladesh sample vital statistics (2018). Bangladesh Bureau of Statistics (BBS), Statistics and Informatics Division (SID), Ministry of Planning, Dhaka

18.Shepherd, J. J., and Stojkov, L. (2007). The logistic population model with slowly varying carrying capacity. ANZIAM Journal, 47: 492. https://doi.org/10.21914/anziamj.v47i0.1058 19.Simon, J., and Malthus, T. R. (2018). An Essay on the principle of population as it affects the future improvement of society (First Edition). The Economics of Population, 219222. https://doi.org/10.4324/9781351291521-31

20.Wali, A. N., Ntubabare, D., and Mboniragira, V. (2011). Mathematical modeling of Rwanda's population growth. Appl. Math. Sci.,5(53): 2617 - 2628

21.Wali, A., Kagoyire, E., \&lcyingeneye, P. (2012). Mathematical modeling of Uganda population growth. Applied Mathematical Sciences, 6(81-84) : 4155-4168.

22.World Bank (2020). Poverty and shared prosperity-2020. Reversals of fortune. Washington, DC: World Bank. () World Bank. https://openknowledge.worldbank.org/handle/10986/3 4496 License: CC BY 3.0 IGO."

23.WEO (2020). A Long and Difficult Ascent. World economic outlook (WEO) report, International Monetary Fund. October 2020 retrieved from https://www.imf.org/en/Publications/ WEO/Issues/2020/09/30/world-economic-outlook-october2020 